\section{Bleak outlook for universities as state budget deficits bite}

\section{Rex Dalton, San Diego}

Public universities in the United States are preparing for severe cuts in some of their research programmes this year, as state legislatures respond to burgeoning budget deficits.

Some institutions - such as the University of California (UC) system, which is already losing $\$ 80$ million from its $\$ 320$ million of annual state-funded research are even now reducing their departmental budgets, axing faculty positions and urgently seeking new sources of income.

At the University of Texas at Austin, administrators are pushing for a new state law to let them raise tuition fees. The University of Colorado at Boulder will cut 33 vacant academic posts as part of a plan to save $\$ 11$ million this year. And the University of Arizona in Tucson may urge professors to try to cover more of their salaries from granting bodies - although most federal agencies prohibit this.

Many state governments begin their legislative processes this month and see cuts in the universities as one way of balancing budgets that have been thrown into deficit by sharply declining tax revenues. Unlike the federal government, most states are legally required to balance their budgets and have little choice but to cut budgets when their revenues decline.

Public universities that receive state funds for research find themselves in an unusual position: while federal research grants flow steadily from the National Institutes of Health and the National Science Foundation, state funds that support their operations and some types of research are likely to be cut.

This situation creates startling inequities at universities, with medical-school research programmes, for example, continuing to expand, while sharp cuts hit other research activities. Such circumstances are already arising on several of the nine UC campuses, which annually receive a total of about $\$ 2.5$ billion in research funds from all sources.

At UC San Diego's Scripps Institution of Oceanography in La Jolla, for instance, state budget cuts of $\$ 1.3$ million in recent months are threatening the maintenance of historic collections of natural objects, as well as operating funds for the research vessel Revelle. "We feel like sacrificial lambs," says Phil Hastings, Scripps' curator of fishes.

Anticipating deeper cuts, Scripps administrators are scrambling to find alternative financing to support their \$148-million annual budget, and are even talking of a 'doomsday scenario' to dissolve the 100-year-

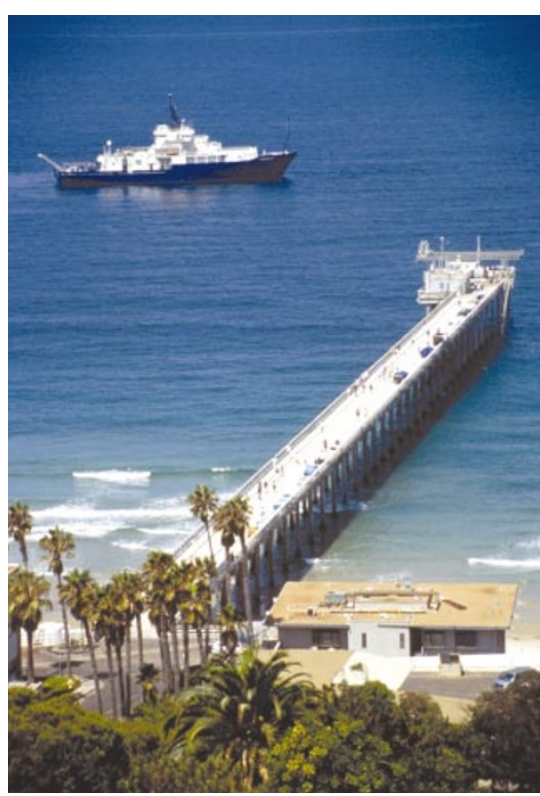

Out on a limb: budget cuts threaten collections and operating funds at the Scripps Institution.

old institution should the state further reduce its \$10-million annual research contribution. "This is the worst since the Depression," says Scripps' deputy administrator Tom Collins.

At UC Davis' College of Agricultural and Environmental Sciences, meanwhile, state cuts of \$3.8 million are hitting the Agriculture Experiment Station, which conducts statewide crop research in one of the world's biggest food-producing regions. About 25 of the 450 faculty positions may be axed.

And biomedical research programmes are not immune, officials say. UC San Francisco was told last month to cut $\$ 10$ million in substance-abuse research, and UC Los Angeles' Brain Injury Research Center, which funds seed grants at all UC campuses, must halve its \$5-million annual budget.

With the announcement in late December that the state of California will face a budget deficit of $\$ 34.8$ billion in the fiscal year that begins in July, university officials and academics are looking with some foreboding to 10 January, when governor Gray Davis will release his budget proposal.

Almost every public university system in the country has a similarly bleak outlook. University of Arizona president Peter Likins, for example, says that the state's board of regents, which also governs Arizona State and Northern Arizona universities, has said that it will take "a radically different perspective" and will enact unspecified new policies to "address enormous financial challenges".
Joint European plan will tackle Africa's killer diseases

Natasha McDowell, London

The New Year is expected to see the birth of an innovative European Union venture that will support clinical trials of treatments for three of Africa's most devastating diseases: AIDS, tuberculosis and malaria.

European governments and institutions are likely to commit $\mathrm{E} 600$ million (US\$620 million) to the venture over five years. Yet some observers are worried that the planned European-Developing Countries Clinical Trials Programme (EDCTP) could stumble in the face of resistance from established national programmes and confusion about its innovative, panEuropean approach to research support.

Medicines that show early promise against the three diseases in small-scale clinical trials often progress no further, mainly because poor countries lack the money and infrastructure for larger trials, the EDCTP's advocates say.

However, when the programme was first conceived in 2001, some developing countries were suspicious of Europe's proposed dominant role. Now, organizers say, it will function as an equal partnership between the European Union and developing countries.

The venture is thought to be the first attempt to create a joint research programme between the European Union, its member states and other European sponsors. "The hope is that a joint research programme will give the EDCTP independence from the usual European bureaucracy," says Brian Greenwood, a malaria specialist at the London School of Hygiene and Tropical Medicine.

Some have voiced concern that effective European coordination may end up as a higher priority than the actual development of drugs or vaccines. But if the venture is run by an independent board of scientific experts, as planned, interference by Commission officials will hopefully be avoided, says Greenwood.

The European Parliament is expected to give final approval for funding of the venture by March, and money could begin to flow by the autumn. One-third of it will come from existing, national clinicalresearch projects, one-third from the European Union and the remainder from research foundations and the pharmaceutical industry. The scientists appointed to the independent board will meet this spring to determine the programme's structure. 